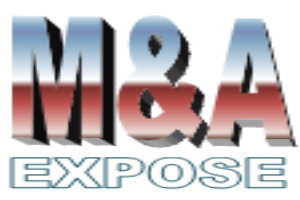

http://jurnal.usahid.ac.id/index .php/accounting
${ }^{1}$ Fakultas Ekonomi dan Bisnis Universitas Sahid dewi.angaraini20081974@am ail.com

${ }^{2}$ Pascasarjana Universitas Indonesa

anisiskamy9689@yahoo.com

\section{Pengaruh Struktur Modal, Profitabilitas dan Ukuran Perusahaan terhadap Nilai Perusahaan}

\author{
Dewi Anggraini ${ }^{1}$, \\ Ani Siska MY ${ }^{2}$
}

\section{Abstrak}

Penelitian ini bertujuan menganalisis pengaruh struktur modal, profitabilitas, dan ukuran perusahaan terhadap nilai perusahaan. Objek penelitian adalah perusahaan-perusahaan dari sektor pariwisata, hotel, dan restauran yang terdaftar di Bursa Efek Indonesia pada periode 2015-2017. Industri pariwisata merupakan industri yang potensial untuk berkembang di Indonesia yang memiliki kekayaan alam dan keragaman budaya. Pertumbuhan pada perusahaan sektor pariwisata sangat menarik untuk melakukan dianalisis kinerjanya. Teknik pengambilan sampel menggunakan metode purposive sampling. Sumber data berasal dari laporan keuangan perusahaan yang dipublikasikan masingmasing perusahaan. Teknik analisis data menggunakan analisis regresi linier berganda. Hasil penelitian menunjukkan bahwa struktur modal dan ukuran perusahaan berpengaruh negatif signifikan terhadap nilai perusahaan. Di sisi lain, profitabilitas tidak berpengaruh terhadap nilai perusahaan.

Kata kunci : struktur modal, profitabilitas, ukuran perusahaan, nilai perusahaan.

\section{Abstract}

This study aims to analyze the effect of capital structure, profitability, and company size toward firm value. The research objects are companies from the tourism, hotel and restaurant sectors which were listed on the Indonesia Stock Exchange in the 2015-2017 period. The tourism industry is a potential industry to develop in Indonesia which has natural wealth and cultural diversity. Growth in tourism sector companies is very interesting to analyze their performance. The sampling technique uses purposive sampling method. Source of data comes from the company's financial statements published by each company. Data analysis techniques used multiple linear regression analysis. The results showed that the capital structure and company size had a significant negative effect on firm value. On the other hand, profitability has no effect on firm value.

Keywords: capital structure, profitability, company size, company value. 


\section{PENDAHULUAN}

Perkembangan dunia usaha Indonesia mengalami peningkatan dari tahun ke tahun. Hal ini didukung dengan adanya nilai tambah yang menyertai suatu perusahaan. Suatu perusahan didirikan dengan tujuan untuk memaksimumkan nilai perusahaan atau kekayaan bagi pemegang saham. Menurut Bringham dan Houston (2007) nilai perusahaan sangat penting karena nilai perusahaan yang tinggi akan diikuti peningkatan kemakmuran bagi pemegang saham. Menurut Sudana (2009) nilai perusahaan dapat dicerminkan oleh harga saham yang relatif stabil, di mana dalam jangka panjang cenderung mengalami kenaikan, semakin tinggi harga saham maka akan semakin tinggi pula nilai perusahaan.

Penentuan nilai perusahaan dapat dilakukan dengan beberapa rasio. Menurut Bringham dan Houston (2007) nilai perusahaan dapat diukur dengan menggunakan rasio Earning per Share (EPS), Price Earning Ratio (PER), Dividen Yield dan Price to Book Value (PBV). Adapun penelitian ini menggunakan Price to Book Value (PBV) sebagai proksi dari nilai perusahaan.

Menurut Alfredo (2011) terdapat beberapa faktor yang mempengaruhi nilai perusahaan yaitu keputusan pendanaan, kebijakan dividen, keputusan investasi, struktur modal, pertumbuhan perusahaan dan ukuran perusahaan. Pada penelitian ini faktor-faktor yang mempengaruhi nilai perusahaan ditinjau dari struktur modal, profitabilitas dan ukuran perusahaan.

Salah satu karakteristik perusahaan di kawasan Asia, termasuk Indonesia adalah kepemilikan terkonsentrasi pada pemegang saham tertentu. Utama (2014) menunjukkan agency problem dalam perusahaan disebabkan oleh tindakan controlling shareholders untuk mendapatkan informasi akurat mengenai operasi bisnis perusahaan daripada minority shareholders. Jensen dan Meckling (1976) memperkenalkan agency problem yang dapat menimbulkan asymmetric information. Jensen (1986) mengemukakan bahwa agency costs yang potensial dari free cash flows dan temuan yang meningkatkan corporate debt load, seperti yang dilakukan dalam leverage buyout, mungkin menjadi sarana yang efektif untuk meningkatkan efisiensi perusahaan salah satunya di dalam working capital management. Smith (1980) mengemukakan adanya adjustment di dalam working capital management akan meningkatkan operating returns pada perusahaan.

Agency problem dalam pengelolaan perusahaan akan berdampak terhadap ketersediaan modal kerja. Modal kerja merupakan inti dari sebuah perusahaan. Modal kerja merupakan area yang sangat sensitif di dalam manajemen keuangan karena berkaitan dengan masalah yang muncul dalam upaya untuk mengelola aset lancar, kewajiban lancar, dan hubungan timbal balik diantara keduanya. Struktur modal yang tepat menjadi tujuan utama perusahaan. Struktur modal perusahaan dapat dianalisis berdasarkan Debt to Equity Ratio (DER), yaitu ratio yang menunjukkan perbandingan antara total hutang terhadap modal sendiri. Semakin tinggi DER, memperlihatkan semakin tinggi risiko yang mungkin akan dihadapi oleh perusahaan karena menunjukkan sumber pendanaan perusahaan dari hutang lebih besar daripada modal sendiri.

Nilai perusahaan dapat pula dipengaruhi oleh besar kecilnya profitabilitas yang dihasilkan oleh perusahaan. Profitabilitas adalah kemampuan perusahaan memperoleh laba dalam hubungannya dengan penjualan, total aktiva maupun modal sendiri. Penelitian ini menggunakan rasio profitabilitas yang diukur dengan Return on Assets (ROA) yaitu rasio yang menunjukkan seberapa besar kemampuan perusahaan dalam menghasilkan laba 
dengan menggunakan aktiva. Hubungan antara profitabilitas dengan nilai perusahaan adalah semakin tinggi profitabilitas perusahaan maka akan akan mengakibatkan nilai perusahaan semakin tinggi, sehingga dapat memaksimumkan kekayaan pemegang saham.

Selain itu, untuk menentukan nilai perusahaan adalah dengan melihat ukuran perusahaan. Ukuran perusahaan menggambarkan besar kecilnya suatu perusahaan yang dapat dilihat dari total asset, jumlah penjualan, rata-rata tingkat penjualan dan rata-rata total aset perusahaan tersebut. Penelitian ini menggunakan total asset sebagai indikator ukuran perusahaan. Ukuran perusahaan mempunyai pengaruh terhadap nilai perusahaan karena jika ukuran perusahaan semakin besar, maka akan semakin memudahkan perusahaan tersebut memperoleh sumber pendanaan baik yang bersifat internal maupun eksternal.

Industri pariwisata merupakan industri yang potensial untuk dikembangkan di Indonesia yang secara alami memiliki kekayaan akan keindahan alam, keragaman dan keunikan budaya. Menurut data Badan Koordinasi Penanaman Modal (BKPM) realisasi investasi di bidang industry pariwisata selama lima tahun terakhir yaitu tahun 2013 sampai dengan 2017 rata-rata tumbuh sebesar $20 \%$ per tahun. Pertumbuhan yang terjadi pada perusahaan sektor pariwisata menarik minat para investor untuk melakukan investasi. Meningkatnya permintaan akan saham tersebut berdampak pada meningkatnya harga saham di pasar, sehingga tujuan jangka panjang perusahaan dapat tercapai karena akan meningkatkan kemakmuran para pemilik yaitu para pemegang saham melalui peningkatan nilai perusahaan.

Berdasarkan latar belakang masalah yang diuraikan di atas, maka rumusan masalah penelitian ini bagaimana pengaruh struktur modal, profitabilitas dan ukuran perusahaan secara simultan berpengaruh signifikan terhadap nilai perusahaan pada perusahaan sektor pariwisata. Adapun tujuan penelitian ini adalah untuk menganalisis pengaruh struktur modal, profitabilitas dan ukuran perusahaan secara simultan berpengaruh signifikan terhadap nilai perusahaan pada perusahaan sektor pariwisata.

\section{TINJAUAN PUSTAKA}

Struktur Modal. Struktur modal perusahaan dapat dianalisis berdasarkan Debt to Equity Ratio (DER). Rasio DER mencerminkan tingkat risiko dari perusahaan. DER menunjukkan komposisi modal sendiri yang dimiliki oleh perusahaan dalam memenuhi liabilitas perusahaan. DER yang tinggi mencerminkan tingginya resiko yang dihadapi investor yang menanamkan dananya di perusahaan yang bersangkutan. Mangondu dan Diantimala (2016), Dhani dan Utama (2017), Anggriawan, Topowijono dan Sudjono (2017) mengemukakan bahwa terdapat hubungan negatif signifikan antara struktur modal dengan nilai perusahaaan. Ang (1997) mengemukakan bahwa semakin tinggi DER maka komposisi total hutang semakin besar dibandingkan dengan total modal perusahaan sendiri, sehingga berdampak semakin besar beban perusahaan terhadap pihak luar (kreditur).

Profitabilitas. Profitabilitas adalah gambaran kinerja perusahaan menghasilkan profit dan sebagai tolak ukur kinerja manajemen perusahaan dalam pengelolaan kekayaan perusahaan. Dalam penelitian ini rasio profitabilitas diukur dengan Return on Assets (ROA) yaitu rasio yang menunjukkan seberapa besar kemampuan perusahaan dalam menghasilkan laba dari aktivanya. Profitabilitas yang tinggi menggambarkan bahwa perusahaan baik kinerjanya sehingga perusahaan mudah untuk mendapatkan hutang atau 
pinjaman dana apabila dibandingkan pada perusahaan yang berkinerja buruk. Wu (2001) berpendapat bahwa kinerja perusahaan berpengaruh signifikan terhadap modal kerja sehingga akan meningkatkan kepercayaan investor serta akan mempermudah manajemen perusahaan untuk menarik modal dalam bentuk saham. Apabila terjadi peningkatan permintaan saham, maka secara tidak langsung akan menaikkan harga saham di pasar modal. Hal serupa juga dikemukakan oleh Hermuningsih (2013) bahwa terdapat hubungan positif signifikan antara profitabilitas dengan nilai perusahaan.

Ukuran Perusahaan. Penelitian ini menggunakan total asset sebagai indikator ukuran perusahaan. Perbedaan ukuran perusahaan berkorelasi dengan kebutuhan modal kerjanya. Ukuran perusahaan dilihat dari total aset, penjualan, serta kapitalisasi pasar. Apabila nilai total aset perusahaan, penjualan, dan kapitalisasi pasar semakin besar maka akan semakin besar ukuran perusahaan. Jadi dengan bertambahnya nilai dari total aset perusahaan maka semakin bertambah pula ekuitas perusahaan, penjualan yang bertambah maka akan semakin besar terjadi perputaran uang dan kapitalisasi pasar akan semakin besar pula. Ukuran perusahaan akan berdampak terhadap rasio keuangan perusahaan (Horrigan, 1965).

Wu et al. (2006) menyatakan perusahaan besar akan memiliki credit rating yang lebih tinggi daripada perusahaan kecil sehingga untuk mendapatkan modal dari pasar modal lebih mudah. Hal ini membuktikan bahwa dalam menjalankan aktivitas operasionalnya, perusahaan besar kebutuhan modal kerjanya lebih sedikit dibandingkan dengan total aset dan penjualannya. Perusahaan besar memiliki arus kas yang lebih stabil daripada perusahaan kecil dan juga dapat melakukan eksploitasi scale economies dalam kegiatan operasinya (Graham et al., 1998; dan Gaud et al., 2005). Selain itu, Ferri dan Jones (1979) mengemukakan bahwa perusahaan besar akan lebih mudah masuk ke pasar uang untuk mendapatkan pinjaman dana dikarenakan memiliki reputasi yang lebih baik dibandingkan perusahaan kecil.

Nilai Perusahaan. Nilai perusahaan merupakan harga yang bersedia dibayar oleh pembeli apabila perusahaan dijual. Tingginya nilai perusahaan akan diikuti oleh tingginya kemakmuran pemegang saham. Nilai perusahaan pada dasarnya mengacu pada harga saham perusahaan karena harga saham perusahaan mencerminkan penilaian investor secara keseluruhan atas setiap ekuitas yang dimiliki. Proksi dari nilai perusahan adalah Price to Book Value (PBV) (Weston dan Copeland, 1992). Price to Book Value (PBV) adalah rasio yang menunjukkan apakah harga saham yang diperdagangkan overvalued (di atas) atau undervalued (di bawah) nilai buku saham tersebut (Fakhruddin dan Hardianto, 2001). Rasio ini mengukur nilai yang diberikan pasar keuangan kepada manajemen dan organisasi sebagai perusahaan yang terus tumbuh. PBV juga menunjukkan seberapa jauh suatu perusahaan mampu menciptakan nilai perusahaan yang relatif terhadap jumlah modal yang diinvestasikan. Semakin tinggi rasio PBV dapat diartikan semakin berhasil perusahaan menciptakan nilai bagi pemegang saham.

Berdasarkan permasalahan penelitian dan tinjauan pustaka, dapat dirumuskan hipotesis sebagai berikut :

H1: Debt to Equity Ratio berpengaruh negatif terhadap Price to Book Value.

$\mathrm{H} 2$ : Return on Assets berpengaruh positif terhadap Price to Book Value.

H3 : Size berpengaruh positif terhadap Price to Book Value. 


\section{METODE PENELITIAN}

Sampel Penelitian. Teknik pengambilan sampel dalam penelitian ini dengan metode purposive sampling. Kriteria sampel penelitian adalah perusahaan di sektor hotel, pariwisata, dan restaurant yang tercatat di BEI yang memiliki laporan keuangan lengkap periode tahun 2015-2017. Sampel dalam penelitian ini terdiri dari 20 perusahaan.

Tabel 1. Pengambilan Sampel berdasarkan Purposive Sampling

\begin{tabular}{ccc}
\hline No & Distribusi Sampel & Total \\
\hline 1 & $\begin{array}{l}\text { Perusahaan sektor hotel, sektor pariwisata, dan sektor restauran } \\
\text { yang terdaftar di Bursa Efek Indonesia (BEI) periode 2015-2017 }\end{array}$ & 25 \\
2 & $\begin{array}{c}\text { Perusahaan sektor hotel, sektor pariwisata, dan sektor restauran } \\
\text { yang laporan keuangannya tidak lengkap }\end{array}$ & $(5)$ \\
\hline & Jumlah sampel penelitian & 20 \\
\hline \multicolumn{2}{c}{ Sumber: Data diolah (2019) }
\end{tabular}

Variabel Operasional. Price to Book Value (PBV) adalah nilai pasar ekuitas pada akhir tahun t-1 dibagi dengan nilai buku ekuitas pada akhir tahun t-1. Nilai pasar ekuitas merupakan harga pasar per saham dikalikan jumlah saham beredar. Robert (1997) menyatakan Price to Book Value (PBV) merupakan rasio pasar untuk mengukur kinerja harga pasar saham terhadap nilai buku dengan formula sebagai berikut :

$\mathrm{PBV}=\frac{\text { Harga Saham }_{i, t}}{\text { Nilai Buku }_{i, t}}$

Debt Equity Ratio (DER) merupakan proksi dari struktur modal yang menunjukkan sejauh mana modal sendiri dapat menganggung seluruh hutang perusahaan.

DER $=\frac{\text { Total Hutang }_{i, t}}{\text { Total Ekuitas }_{i, t}}$

Return on Assets (ROA) adalah pengukuran atas profitabilitas dari perusahaan yang akan memberikan gambaran dari modal yang ditanamkan pada aset pada tingkat pengembalian yang diperoleh perusahaan (Ross,Westerfield, dan Jordan, 2016).

$R O A_{i, t}=\frac{\text { Net Income }_{i, t}}{\text { Total } \operatorname{Assets}_{i, t}}$

Ukuran perusahaan memiliki hubungan dengan modal kerja perusahaan (Nakamura dan Polombini, 2008; dan Gill, 2011), karena perusahaan besar tidak memerlukan persediaan banyak dan membutuhkan ketersediaan modal rendah. Gill (2011) dan Wu (2006) menggunakan logarithma normal total aset sebagai proksi ukuran perusahaan.

$\operatorname{SIZE}_{i, t}=L N\left(\right.$ Total Assets $\left._{i, t}\right)$ 
Teknik Analisis. Dalam penelitian ini digunakan teknik analisis regresi linier berganda, sebagai berikut :

$$
\begin{aligned}
& \operatorname{PBV}_{i, t}=\beta_{0}+\beta_{1} \mathrm{DER}_{i, t}+\beta_{2} \mathrm{ROA}_{i, t}+\beta_{3} \mathrm{SIZE}_{i, t}+\varepsilon_{i, t} \\
& \beta \quad=\text { Intercept } \\
& \mathrm{PBV}_{i, t}=\text { Price to Book Value } \\
& \mathrm{DER}_{i, t}=\text { Debt to Equity Ratio } \\
& \operatorname{SIZE}_{i, t}=\text { Ukuran Perusahaan } \\
& \varepsilon_{i, t} \quad=\text { Standard error }
\end{aligned}
$$

\section{HASIL DAN PEMBAHASAN}

Statistik Deskriptif . Tabel 2 mempresentasikan deskriptif statistik dari data penelitian.

Tabel 2. Statistik Deskriptif

\begin{tabular}{ccccc}
\hline & Mean & Minimum & Maximum & Standar Deviasi \\
\hline PBV & 1.371 & 0.037 & 3.469 & 0.096 \\
DER & 1.191 & 0.027 & 7.950 & 1.519 \\
ROA & 1.171 & $-0,140$ & 8.870 & 6.942 \\
Size & 25.918 & 19.480 & 30.360 & 2.941 \\
Sampel & 20 & 20 & 20 & 20 \\
Observasi & 60 & 60 & 60 & 60 \\
\hline
\end{tabular}

Sumber : Data diolah (Eviews 10)

Sampel penelitian terdiri dari 20 perusahaan meliputi sektor yaitu sektor hotel, pariwisata, dan restaurant pada periode tahun 2015-2017 sehingga jumlah observasi sebesar 60. Pengujian statistik deskriptif dilakukan untuk memberikan penjelasan mengenai nilai minimum, nilai maksimum, nilai rata-rata, dan nilai standar deviasi dari masing-masing variabel. Mean PBV sebesar 1.371 yang berarti bahwa harga saham yang diperdagangkan oleh perusahaan lebih besar dari nilai wajarnya karena nilai PBV yang lebih dari 1 menunjukkan bahwa nilai perusahaan mengalami peningkatan. Mean DER sebesar 1.191 yang berarti bahwa rata-rata perusahaan mampu untuk membayar hutangnya dengan menggunakan modal perusahaan sebesar 1.191 kali dan jumlah hutang perusahaan sama dengan jumlah modal perusahaan.

Profitabilitas perusahaan yang diproksikan dengan ROA memiliki nilai minimum sebesar $-14 \%$ yang berarti bahwa ada beberapa perusahaan yang mengalami kerugian. Sedangkan Size memiliki nilai minimum sebesar 25.918. Dalam uji normalitas, data penelitian didapatkan hasil data normal, homokedastisitas, dan tidak ada multikolineritas maupun autokorelasi.

Analisis Regresi Linier Berganda. Penelitian ini menggunakan data panel. Hasil estimasi pemilihan model data panel dengan menggunakan chow test dan hausman test, menunjukkan bahwa estimasi menggunakan fixed effect (Tabel 3). 
Tabel 3. Hasil Pemilihan Model Estimasi

\begin{tabular}{cccc}
\hline $\begin{array}{c}\text { Metode } \\
\text { Pengujian } \\
\text { Model }\end{array}$ & $\begin{array}{c}\text { Dengan } \alpha=5 \% \\
\text { Probabilitas } \\
\text { (F-Stat) }\end{array}$ & Keputusan & $\begin{array}{c}\text { Model } \\
\text { Regresi }\end{array}$ \\
\hline Chow Test & 0 & Tolak H0 & Fixed Effect \\
Hausman Test & 0 & Tolak H0 & Fixed Effect \\
\hline Sumber: Data diolah (Eviews 10) & &
\end{tabular}

Brooks (2014) mengemukakan bahwa pemilihan model data panel antara fixed effect dan random effect dilakukan berdasarkan pemilihan unit dari sampel penelitian. Selain didukung hasil pengujian chow test dan hausman test, juga didukung dari tidak terpilihnya sampel secara acak namun terpenuhi kriterianya.

Tabel 4. Hasil Uji Hipotesis

\begin{tabular}{|c|c|c|c|}
\hline \multirow{2}{*}{$\begin{array}{c}\text { Variabel } \\
\text { Independen }\end{array}$} & \multicolumn{3}{|c|}{ Variabel Dependen PBV } \\
\hline & Koefisien & $\begin{array}{c}\text { t- } \\
\text { Statistik }\end{array}$ & $\begin{array}{c}\text { Prob. } 1 \\
\text { tail }\end{array}$ \\
\hline DER & -0.003 & -4.787 & $0.000^{\star \star *}$ \\
\hline ROA & -0.001 & -0.976 & 0.331 \\
\hline SIZE & -0.007 & -2.034 & $0.047^{\star *}$ \\
\hline Jumlah Observasi & \multicolumn{3}{|c|}{20} \\
\hline Cross-Section & \multicolumn{3}{|c|}{60} \\
\hline Metode & \multicolumn{3}{|c|}{ Fixed Effect Model } \\
\hline$R$-Squared & \multicolumn{3}{|c|}{0.759} \\
\hline Adj. R-Squared & \multicolumn{3}{|c|}{0.632} \\
\hline Prob (F-Statistik) & \multicolumn{3}{|c|}{0.021} \\
\hline
\end{tabular}

Berdasarkan Tabel 4, DER memilki hubungan negatif signifikan terhadap PBV yang berarti sesuai dengan hipotesis pertama $(\mathrm{H} 1)$. Hasil penelitian ini mendukung penelitian Dewi dan Wirajaya (2013) yang menyatakan bahwa struktur modal memilki pengaruh negatif signifikan terhadap nilai perusahaan. Hubungan negatif antara DER dengan PBV pada Tabel 1 diketahui bahwa nilai mean DER pada perusahaan sektor hotel, pariwisata, dan restauran di atas 1 . Hal ini berarti perusahaan menggunakan hutangnya lebih besar dari modal sendiri. Penggunaan hutang yang tinggi akan menyebabkan timbulnya biaya kebangkrutan, biaya keagenan, beban bunga yang semakin besar. Apabila biaya kebangkrutan semakin besar, tingkat keuntungan yang disyaratkan oleh pemegang saham juga semakin tinggi. Biaya modal hutang juga akan semakin tinggi karena pemberi pinjaman akan membebankan bunga yang tinggi sebagai kompensasi kenaikan risiko kebangkrutan. Oleh karena itu, perusahaan akan terus menggunakan hutang apabila manfaat hutang (penghematan pajak dari hutang) masih lebih besar dibandingkan dengan biaya kebangkrutan. Jika biaya kebangkrutan lebih besar dibandingkan dengan penghematan 
pajak dari hutang, perusahaan akan menurunkan tingkat hutangnya. Tingkat hutang yang optimal terjadi pada saat tambahan penghematan pajak sama dengan tambahan biaya kebangkrutan. Sehingga pada teori Trade Off menjelaskan bahwa sebelum mencapai titik maksimum, hutang akan lebih murah daripada penjualan saham karena adanya tax shield. Implikasinya adalah semakin tinggi hutang maka akan semakin nilai perusahaan. Namun setelah mencapai titik maksimum, penggunaan hutang oleh perusahaan menjadi tidak menarik karena perusahaan harus menanggung biaya keagenan, kebangkrutan serta biaya bunga yang menyebabkan nilai perusahaan turun.

Hasil penelitian memperlihatkan bahwa profitabilitas yang diproksikan dengan ROA tidak berpengaruh signifikan terhadap nilai perusahaan. Hasil penelitian ini bertolak belakang dengan hasil penelitian Hermuningsih (2013) di mana terdapat hubungan positif dan signifikan antara profitabilitas dengan nilai perusahaan. Hasil penelitian Size terhadap PBV memiliki pengaruh negatif signifikan yang berarti bahwa semakin besar ukuran perusahaan maka semakin kecil nilai dari PBV atau dengan kata lain semakin kecil struktur modal yang dimiliki perusahaan. Ukuran perusahan merupakan kemampuan perusahan dalam memperoleh laba. Hasil penelitian ini bertolak belakang dengan hasil penelitian Hermuningsih (2013) bahwa terdapat hubungan positif signifikan antara ukuran perusahaan dengan nilai perusahaan.

\section{KESIMPULAN}

Penelitian ini menganalisis pengaruh struktur modal yang diproksikan debt to equity ratio (DER), profitabilitas yang diproksikan return on assets (ROA), dan ukuran perusahaan (size) yang diproksikan logarithma natural dari total asset terhadap nilai perusahaan yang diproksikan price to book value (PBV). Sampel dalam penelitian ini sebanyak 20 perusahaan dari tiga sektor yaitu sektor hotel, sektor pariwisata, dan sektor resaturan yang terdaftar di BEI dan memilki laporan keuangan lengkap pada periode 2015-2017.

Hasil penelitian menunjukkan bahwa DER dan Size memilki pengaruh negatif signifikan terhadap PBV yang berarti bahwa apabila nilai dari DER atau pun SIZE semakin besar maka PBV atau nilai perusahaan akan semakin kecil. Berbeda dengan hubungan ROA dan PBV yang tidak memiliki pengaruh signifikan terhadap PBV.

\section{DAFTAR PUSTAKA}

Mahendra, Alfredo. 2011. Pengaruh Kinerja Keuangan terhadap Nilai Perusahaan (Kebijakan Dividen Sebagai Variabel Moderating Pada Perusahaan Manufaktur di BEI). Universitas Udayana.

Anggriawan F. Topowijono. dan Sudjono N. 2017. Pengaruh Struktur Modal Terhadap Nilai Perusahaan (Studi pada perusahaan Subsektor Makan dan Minuman Yang Listing di Bursa Efek Indonesia). Jurnal Administrasi Bisnis. Vol 50. No. 4.

Brigham, Eugene F. Houston, dan Joel F. 2007. Essentials of Financial Management. Cengage Learning.

Brooks, Chris. 2014. Introductory Economics for Finance. Third Edition: Cambridge University Press. 
Dewi, Ayu Sri Mahatma. Ary, Wirajaya. 2013. Pengaruh Struktur Modal, Profitabilitas dan Ukuran Perusahaan Pada Nilai Perusahaan. E-Jurnal Akuntansi Universitas Udayana, 358-372.

Dhani PI, Utama S Gde A.A. 2017. Pengaruh Pertumbuhan Perusahaan, Struktur Modal dan Profitabilitas Terhadap Nilai Perusahaan. Jurnal Riset Akuntansi dan Bisnis. Volume 2. No. 1: 135-148.

Fakhruddin dan Hadianto, Sopian. 2001. Perangkat dan Model Analisis Investasi di Pasar Modal, Buku Satu. Jakarta. Elex Media Komputindo.

Fama, EF. and French, KR. 1992. The Cross-Section of Expected Stock Returns. The Journal of Finance.

Gill, A. 2011. Factors that Influenceworking Capital Requirement in Canada. Economics and Finance Review. Volume 1. No. 3: 30-40.

Hermuningsih Sri. 2013. Pengaruh Profitabilitas, Peluang Pertumbuhan, Struktur Modal Terhadap Nilai Perusahaan Pada Perusahaan Publik di Indonesia, Buletin Ekonomi Moneter dan Perbankan, Bank Indonesia. Volume 16. No. 2: 1-22.

Hutchison, D. P., Farris M. T. II, and Anders, S. B. 2007. Cash to Cash Analysis and Management : Useful Performance Measures for Improving Profitability. The CPA Journal. Volume 77. No. 8: 42-47.

Mangondu R dan Diantimala Y. 2016. Pengaruh Struktur Modal Terhadap Nila Perusahaan dan KInerja Perusahaan Pada Perusahaan Perbankan Yang Terdaftar di Bursa Efek Indonesia. Jurnal Dinamika Akuntansi dan Bisnis (JDAB). Volume 3. No. 1: 62-69.

Michael, Jensen., \& William H, Meckling. 1976. Theory of The Firm: Managerial Behaviour, Agency Costs and Ownership Structure. Journal of Financial Economics. 305-360.

Michael, Jensen. 1986. Agency Costs of Free Cash Flow, Corporate Finance, and Takeovers. The American Economic Revie. Volume 2. No 76: 323-329.

Robbert Ang. 1997. Buku Pintar: Pasar Modal Indonesia (The Intelligent Guide to Indonesian Capital Market). Mediasoft Indonesia, First Edition.

Ross, Westerfield, and Jordan. 2016. Essentials of Corporate Finance. Ninth Edition: McGraw-Hill New York.

Sudana, I Made. 2009. Manajemen Keuangan: Teori dan Praktek. Surabaya. Airlangga University Press.

Utama, C. A. and S. Utama. 2014. Determinants of Disclosure Level of Related Party Transactions in Indonesia. International Journal Disclosure and Governance. Volume 1. No 4: 341-365.

Weston, J.F. \& Copeland, T.E. 1992. Managerial Finance, (9th ed). The Dryden Press. 